\title{
Analysis of Mortality in Africanized Honey Bee Colonies with High Levels of Infestation by Varroa destructor
}

by

Igor Médici de Mattos ${ }^{1 *} \&$ José Chaud-Netto ${ }^{1}$

\section{ABSTRACT}

The mite Varroa destructor (Anderson \& Treuman 2000) is one of the world's most important plagues of apiculture. In Brazil this mite does not encounter good conditions for parasitism because weather conditions are not ideal for its maintenance, and some strains of Africanized honey bees are resistant to the parasite. This status is reflected in the low number of dead colonies caused by varroatosis and also the stability of infestation levels. The aim of this study was to evaluate the damage caused by mite infestations in hives with higher levels of infestation than the ones considered normal for Brazilian apiaries. The level of infestation in each colony was determined and the mortality rates of parasitized bees during development were periodically recorded. The G Test of Independence and a Test of Proportions were used to compare the data. The rates of mortality of pupae and larvae were mostly proportional to the level of infestation in each colony. All colonies showed mortality rates significantly higher than the control one. In Africanized honeybee colonies with high rates of infestation by Varroa destructor mortality rates varied from $19.27 \%$ to $23.28 \%$ in pupae $(\bar{X}=21.27 \%)$ and from $15.71 \%$ to $16.15 \%$ in larvae ( $\bar{X}=15.93 \%$ ), against $3.85 \%$ and $3.74 \%$ in the control colony, respectively. In the parasitized colonies the average rates of mortality caused by the hurtful effects of the mite were, respectively, 5.52 and 4.26 times greater in those two developmental stages. Thus it can be concluded that even in tropical regions, like Brazil, it is necessary to give special attention to the levels of mite infestation (IR), particularly where the IR tends to be higher.

Keywords: Africanized honeybees, Apis mellifera, Varroa destructor, mortality analysis, development.

\footnotetext{
${ }^{1}$ Departamento de Biologia, Instituto de Biociências de Rio Claro, Universidade Estadual Paulista -UNESP, Av. 24-A no 1515, CEP 13506-900 - Rio Claro, São Paulo, Brasil.

*Corresponding author. e-mail: igormmattos@yahoo.com.br
} 


\section{INTRODUCTION}

Varroa jacobsoni Oudemans was described as an ectoparasitic mite of the Eastern honeybee, Apis cerana Fabricius. This parasite is incapable of reproducingon Apismellifera brood (Anderson 1994, Anderson \& Sukarsih 1996). The mite that parasites the Western honeybees (Apis mellifera Fabricius) presents size variations and is a different species, renamed as Varroa destructor (Anderson \& Trueman 2000).

This new species started causing serious damages to these bees and consequently to apiculture (lfantidis \& Rosenkranz 1988, Erickson et al. 1994, Donze' \& Guerin 1994, Anderson \& Trueman 2000). The extensive damage caused by Varroa destructor is often related to the brief period of coevolution between this parasite and the new host, since, except for African and Africanized honeybees, the other races of Apis mellifera did not develop an effective defense behavior against the mite (De Jong 1984, De Jonget al. 1984, Moretto et al. 1993, De Jong 1997, Boecking \& Genersch 2008).

The varroatosis, as the parasitism is called, causes serious harm to the developing bees as well as the adults (Delfinado-Baker et al. 1992, De Jong 1997, Beestma et al. 1999). As a consequence of parasitism during development, newly emerged honeybee workers present reduced weight, wing deformations and changes in several other appendices (mainly the legs), besides a significant decrease in the size of the abdomen. Other signs, such as hypopharyngeal gland malformation and decreased life span (in adults) are also commonly found (De Jong et al. 1982, Schneider \& Drescher 1987, Schatton-Gadelmayer \& Engels 1988, Beestma et al. 1989, Bowen-Walker \& Gunn 2001, Romero-Vera \& Otero-Colina 2002, Garedew et al. 2004, Genersch 2005, Kralj \& Fuchs 2006). Furthermore, the mites act as a vector for the transmission of some viruses, for example, DWV (Deformed Wing Virus) (Ball 1988, Martin 1998, Bowen-Walker et al. 1999, Martin 2001, Tentcheva et al. 2006).

Some researchers relate the Varroa mite to CCD (Colony Collapse Disorder) and van Engelsdorp et al. (2009) suggested that this syndrome originates from an interaction between pathogens and other factors that cause stress to the colony, whereas the mite could suppress some immune responses of its host. According to Le Conte et al. (2010) the hypothesis that CCD is due to the parasitic mite is feasible and, indeed, is reinforced by studies carried 
out by van Engelsdorp et al. (2009). CCD was first reported in colonies of A. mellifera in the U.S.A. Interestingly, at the time of collapse, the infestation levels of Varroa had not reached levels known to cause economic damage or declining populations (van Engelsdorp et al. 2009). Considering this information, we may conclude that Varroa can play an important role as a cause of CCD even in Brazil, where the infestation rates by the mite are not commonly high.

Considering this worldwide scenario of damages, controlling the mite has become necessary. But the use of acaricids has shown no satisfactory results because of important drawbacks such as contamination of bee products and resistant mite lineages (Milani 1995, 1999, Hillesheim et al. 1996, Jacobs et al. 1997, Elzen et al. 1998, 2000, Wallner 1999, Bogdanov 2006, Martel et al. 2007).

African honeybees and their hybrids (Africanized Honey Bees - AHB) have greater tolerance to Varroa destructor infestations, with few reports of major damage (De Jong et al. 1984, Montiel \& Piola 1976, Gusman-Novoa et al. 1999).

In Brazil, where AHB are commonly used, the levels of infestation have remained stable since 1978 (between $2 \%$ and 3\%, reaching 5\% in some apiaries) (Gonçalves 1986, Rocha \& Almeida-Lara 1994), but as shown by Mattos \& Chaud-Netto (2011) even at those levels of infestation the death rates of developing bees could be 2.28 times greater (for pupae) to 2.65 times greater (for larvae) than those found in less-infested colonies.

So, it is apparent that new information and research about the relationship between the mite and its host, such as the harm caused by the parasite, are very important to the development of new methods of controlling and preventing varroatosis.

The aim of this study was to quantify the damages caused by mites in colonies with high levels of infestation, in relation to those considered common in tropical areas of Brazil (2-5\%), by registering the loss of individuals during development.

\section{MATERIAL AND METHODS}

To quantify the level of infestation in each colony the method of Stort et al. (1981) was used: frames covered by bees were removed from colonies 
of the apiary from UNESP Campus at Rio Claro, and the workers swept with a brush into containers load with $150 \mathrm{ml}$ of $96 \%$ alcohol (volume corresponding to about 300 bees). Next the samples were placed in a shaker for 30 minutes so that the mites still attached to the bees could be separated. The samples were then transferred to plastic containers fitted internally with a fine metallic net which separates bees and mites. All bees (NB) and mites (NM) were counted and the Infestation Rate (IR) was calculated: $I R=(N M / N B)$ $\mathrm{x} 100$. This experimental procedure was repeated three times with one week interval between samples collected. Then an average of three data obtained was calculated in order to determine the final degree of parasitism in each colony, making possible the establishment of a rank of infestation.

Three colonies were chosen from the rank of degree of infestation, two of which had levels of infestation higher than values usually found in Brazilian apiaries (between $2 \%$ and $5 \%$ ). The colony named $\mathrm{C} 1$ presented $\mathrm{IR}=15.91 \%$, while the colony $\mathrm{C} 11$ had $\mathrm{IR}=10.96 \%$. The colony that showed the lowest degree of infestation (C20: 0.20\%) was used as a control.

The experiment began with the introduction of an empty comb with a demarcated area in each colony. That area contains approximately 500 brood cells. After the queens performed postures in the demarcated area, the combs were periodically inspected in order to follow the bees' development. The technique described by Garófalo (1977) was used to quantify the loss of developing bees.

The results were analyzed using the software BioStat 5.0 (Ayres et al. 2007). The binomial statistical test (Two Proportions) and the G Test of Independence were used to compare the data.

\section{RESULTS AND DISCUSSION}

The results showed that the rate of mortality of pupae was proportional to the degree of infestation in each colony, i.e., colonies with major rates of infestation presented higher frequencies of individuals died in the pupa stage (Fig. 1). The G Test of Independence indicated a significant interaction between the mortality of pupae and the infestation rates (Test $G=117.33$; $\mathrm{p}<0.0001$; Test-G (Williams) = 117. 04; $\mathrm{p}<0.0001$ ).

In the colony used as control (C20) the experiment was performed during three complete cycles of development of Apis mellifera workers (Table 1; Fig. 
3). In this period 1220 pupae were observed, but 47 did not complete their development, which represents 3.85\% loss.

Colony $\mathrm{C} 11$ was studied by a period of two cycles for worker brood (Table 2; Fig. 4). From 638 pupae observed in the experiment, 123 did not survive (19.27\%). The test of proportions indicated a significant difference between the mortality rates of pupae obtained for the control colony (C20) and colony C11 ( $\mathrm{Z}=10.95$; $\mathrm{p}<0.0001)$.

In colony $\mathrm{C} 1$, with the highest infestation rate, a proportional death rate for pupae was observed (Table 3; Fig. 5). During three cycles of development 1224 pupae were observed, and 285 of them did not complete the cycle (23.28\%). A significant difference between the mortality rates of pupae obtained for the control colony (C20) and the colony $\mathrm{C} 1(\mathrm{Z}=14.02$; $\mathrm{p}<0.0001)$ was detected.

The tests concerning the death of larvae showed a similar trend to those of pupae, i.e., the colony with the higher rate of infestation showed the higher frequency of dead larvae (Fig. 2). The G test of independence confirmed the existence of a significant interaction between the mortality of larvae and the

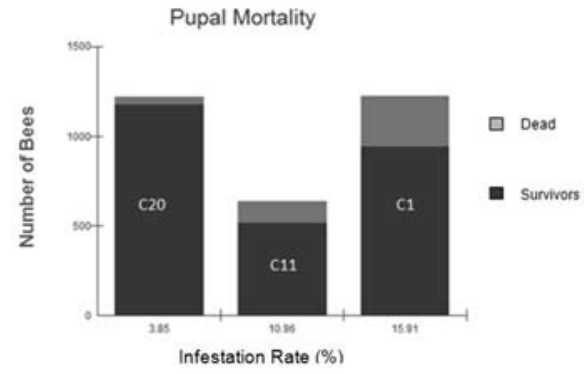

Fig 1. Number of dead pupae (grey) recorded in Africanized honeybee colonies infested by Varroa destructor.

Table 1. Percentage survival during each immature stage in colony $\mathrm{C} 20$.

\begin{tabular}{|c|c|c|c|c|}
\hline & $1^{\circ}$ Cycle & $2^{\circ}$ Cycle & $3^{\circ}$ Cycle \\
\hline \multirow{5}{*}{ Days } & No. Eggs & 386 & 414 & 420 \\
\hline & $0-1$ & $100 \%$ & $100 \%$ & $100 \%$ \\
\hline & $1-2$ & $98.7 \%$ & $98.55 \%$ & $100 \%$ \\
\hline & $2-3$ & $99.47 \%$ & $94.85 \%$ & $99.52 \%$ \\
\hline & $3-4$ & $99.2 \%$ & $100 \%$ & $99.76 \%$ \\
\hline \multicolumn{2}{|c|}{ Survival } & $97.4 \%$ & $93.47 \%$ & $99.28 \%$ \\
\hline \multirow{6}{*}{ Days } & Larvae & 376 & 387 & 417 \\
\hline & $0-1$ & $100 \%$ & $99.48 \%$ & $100 \%$ \\
\hline & $1-2$ & $99.73 \%$ & $97.4 \%$ & $99.52 \%$ \\
\hline & $2-3$ & $96 \%$ & $99.2 \%$ & $98.79 \%$ \\
\hline & $3-4$ & $99.72 \%$ & $99.46 \%$ & $99.26 \%$ \\
\hline & $4-5$ & $100 \%$ & $100 \%$ & $99.50 \%$ \\
\hline \multicolumn{2}{|c|}{ Survival } & $95.47 \%$ & $95.6 \%$ & $97.12 \%$ \\
\hline \multirow{2}{*}{ Days } & Pupae & 359 & 370 & 405 \\
\hline & $0-12$ & $95.26 \%$ & $98.91 \%$ & $94.09 \%$ \\
\hline \multicolumn{2}{|c|}{ No. Adults produced } & 342 & 366 & 379 \\
\hline \multicolumn{2}{|c|}{ Survival } & $88.6 \%$ & $88.4 \%$ & $93.58 \%$ \\
\hline
\end{tabular}


number of mites (Test $\mathrm{G}=73.85$; $\mathrm{p}<0.0001$; Test-G (Williams) $=$ 73.64; $\mathrm{p}<0.0001)$.

In colony C20 (control group), 1229 worker larvae were followed for three cycles of development (Table 1; Fig. 3). In this period, 46 dead larvae were recorded, corresponding to a mortality rate of $3.74 \%$.

In C11 439 larvae were registered and 69 died before completing their development (15.71\%). The test of proportions indicated a significant difference between the mortality rates of larvae obtained for $\mathrm{C} 11$ and $\mathrm{C} 20$ colonies $(\mathrm{Z}=7$. 39; $\mathrm{p}<0.0001$ ). (Table 2; Fig. 4).

In C1 984 larvae were observed (Table 3; Fig. 5), but 159 of them did not survive (16.15\%). A significant difference between the mortality rates of larvae obtained for $\mathrm{C} 1$ and $\mathrm{C} 20$ colonies $(\mathrm{Z}=8.72$; $\mathrm{p}<0.0001)$ was also detected.

Survival tables were made with basis on the total number of eggs laid in the observation area (Garófalo 1977). Tables 1, 2 and 3 show the percentage of survivors during the stages of development in each

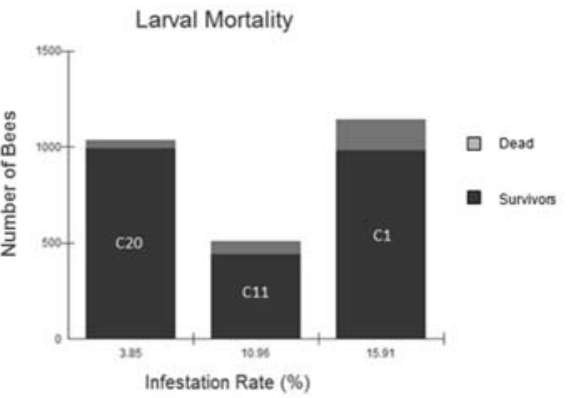

Fig. 2. Number of dead larvae (grey) recorded in colonies infested by Varroa destructor.

Table 2. Percentage survival during each immature stage in colony C11.

\begin{tabular}{|c|c|c|c|}
\hline & & $1^{\circ}$ Cycle & $2^{\circ}$ Cycle \\
\hline \multirow{5}{*}{ Days } & No. Eggs & 240 & 494 \\
\hline & $0-1$ & $100 \%$ & $100 \%$ \\
\hline & $1-2$ & $98.75 \%$ & $99.79 \%$ \\
\hline & $2-3$ & $100 \%$ & $99.59 \%$ \\
\hline & $3-4$ & $100 \%$ & $99.79 \%$ \\
\hline \multicolumn{2}{|c|}{ Survival } & $98.75 \%$ & $99.19 \%$ \\
\hline \multirow{6}{*}{ Days } & Larvae & 237 & 490 \\
\hline & $0-1$ & $97.04 \%$ & $100 \%$ \\
\hline & $1-2$ & $95.65 \%$ & $97.75 \%$ \\
\hline & $2-3$ & $91.81 \%$ & $99.58 \%$ \\
\hline & $3-4$ & $96.53 \%$ & $98.95 \%$ \\
\hline & $4-5$ & $96.92 \%$ & $99.36 \%$ \\
\hline \multicolumn{2}{|c|}{ Survival } & $82.17 \%$ & $95.71 \%$ \\
\hline \multirow{2}{*}{ Days } & Pupae & 189 & 469 \\
\hline & $0-12$ & $48.14 \%$ & $94.66 \%$ \\
\hline \multicolumn{2}{|c|}{ No. Adults produced } & 91 & 444 \\
\hline \multicolumn{2}{|c|}{ Survival } & $37.91 \%$ & $89.87 \%$ \\
\hline
\end{tabular}
colony. In those tables day $3-4$ was included in the egg stage and day 5-6 was included in the larval stage in order to show the mortality in these periods (considering that the mor- 
phological alterations to the next stage had not already occurred) (Garófalo 1977). The duration of the pupae stage was considered to be 12 days, as Garófalo (1977) said it is the most common duration. In all tables the frequency of survival in each period of 24 hours was calculated, so that a general survival frequency was calculated in each stage of development. At last the number of adults produced was compared with the number of eggs laid and the final frequency of survival was calculated. Figs. 3, 4 and 5 show the survival curves during those stages, in each colony.

The G Test of independence was used to verify if there was
Table 3. Percentage survival during each immature stage in colony $\mathrm{C} 1$.

\begin{tabular}{|c|c|c|c|c|}
\hline & $1^{\circ}$ Cycle & $2^{\circ}$ Cycle & $3^{\circ} \mathrm{Cycle}$ \\
\hline \multirow{5}{*}{ Days } & No. Eggs & 487 & 373 & 364 \\
\hline & $0-1$ & $98.35 \%$ & $99.73 \%$ & $100 \%$ \\
\hline & $1-2$ & $98.74 \%$ & $100 \%$ & $97.52 \%$ \\
\hline & $2-3$ & $99.15 \%$ & $98.65 \%$ & $99.15 \%$ \\
\hline & $3-4$ & $100 \%$ & $99.18 \%$ & $99.71 \%$ \\
\hline \multicolumn{2}{|c|}{ Survival } & $96.3 \%$ & $97.58 \%$ & $96.42 \%$ \\
\hline \multirow{6}{*}{ Days } & Larvae & 469 & 364 & 351 \\
\hline & $0-1$ & $100 \%$ & $99.17 \%$ & $100 \%$ \\
\hline & $1-2$ & $89.97 \%$ & $98.33 \%$ & $97.43 \%$ \\
\hline & $2-3$ & $94.07 \%$ & $96.05 \%$ & $93.56 \%$ \\
\hline & $3-4$ & $98.99 \%$ & $98.24 \%$ & $97.18 \%$ \\
\hline & $4-5$ & $96.69 \%$ & $99.7 \%$ & $100 \%$ \\
\hline \multicolumn{2}{|c|}{ Survival } & $81.02 \%$ & $89.54 \%$ & $88.6 \%$ \\
\hline \multirow{2}{*}{ Days } & Pupae & 380 & 334 & 311 \\
\hline & $0-12$ & $74.47 \%$ & $78.14 \%$ & $63.02 \%$ \\
\hline \multicolumn{2}{|c|}{ No. Adults produced } & 283 & 261 & 196 \\
\hline \multicolumn{2}{|c|}{ Survival } & $58.11 \%$ & $69.97 \%$ & $53.84 \%$ \\
\hline
\end{tabular}

\section{Survival curves for C20}

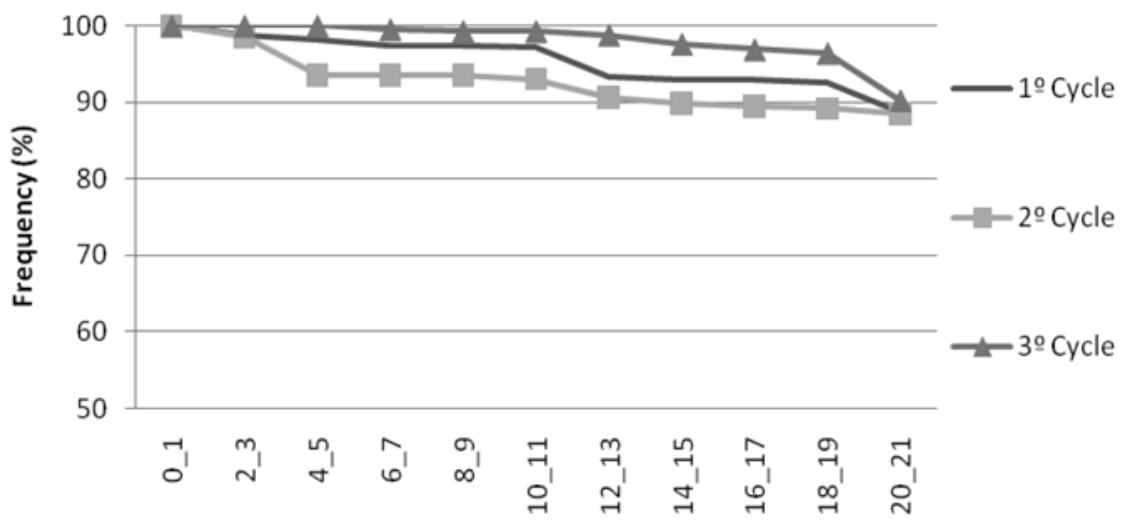

Duration in days

Fig. 3. Survival Curves for immature stages in colony C20. 
any relationship among the total number of dead larvae and the number of larval deaths that occurred between the $3^{\text {rd }}$ and $4^{\text {th }}$ days of larval life. This interval of days was characterized by Laidlaw et al. (1956) as the period of main effects of inbreeding. The statistical analysis indicated no significant

\section{Survival curves for $\mathrm{C} 11$}

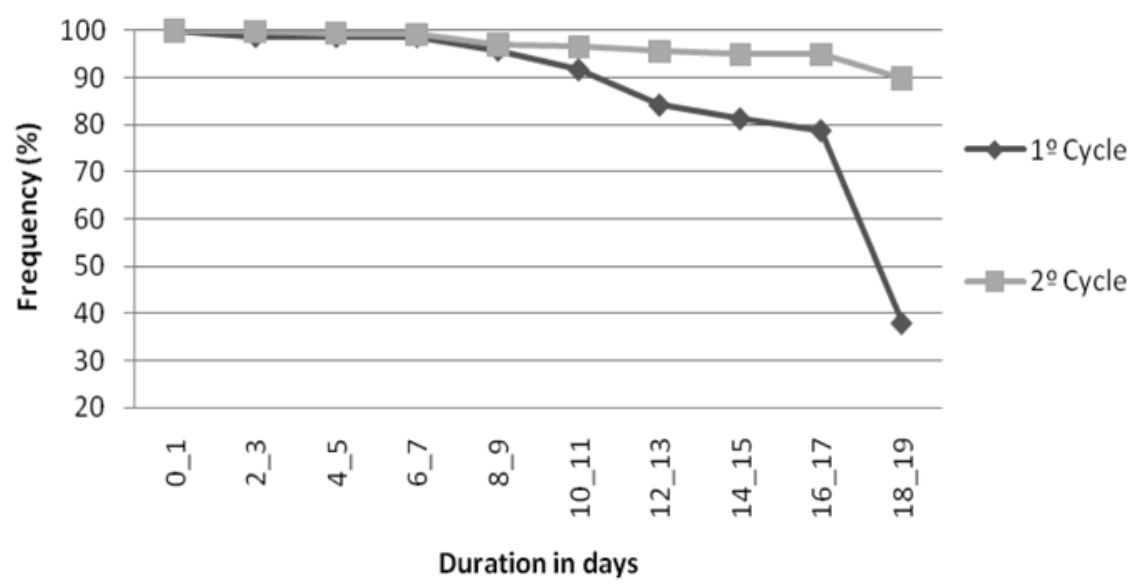

Fig. 4. Survival Curves for immature stages in colony C11.

\section{Survival curves for $\mathrm{C} 1$}

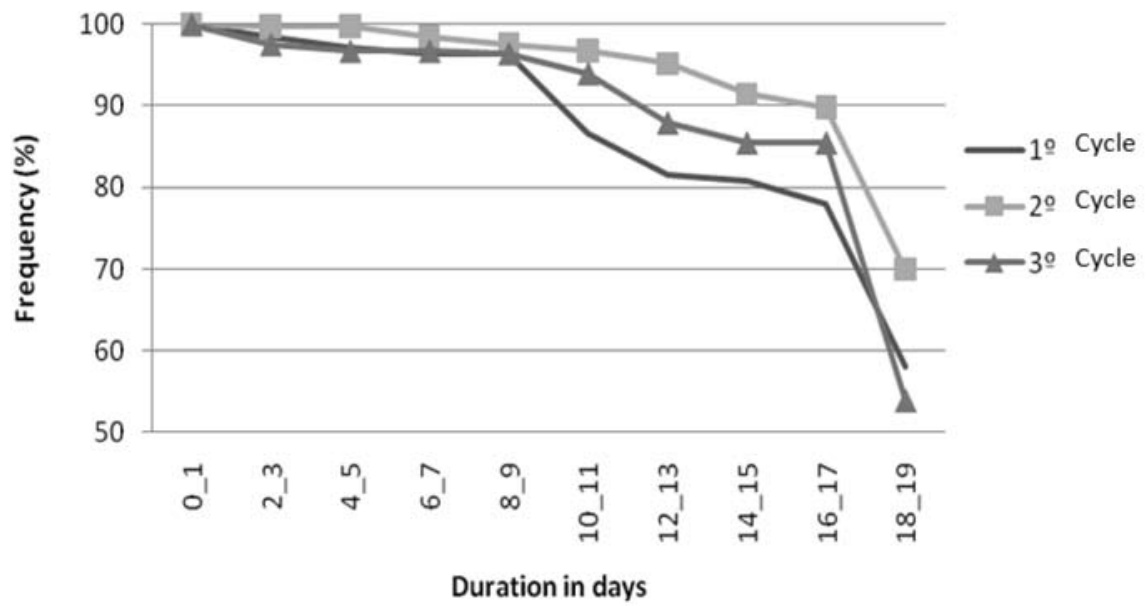

Fig. 5. Survival Curves for immature stages in colony $\mathrm{C} 1$ 
interaction among the parameters tested $(\mathrm{G}$ Test $=11.86, \mathrm{P}=0.1050 ; \mathrm{G}$ Test (Williams) $=11.21, \mathrm{P}=0.1297)$.

Laidlaw et al. (1956) observed that in colonies with low genetic variability (major inbreeding) the developing bees show higher rates of mortality on the $3^{\text {rd }}$ and $4^{\text {th }}$ days of larval life. Mattos \& Chaud-Netto (2011) have shown similar correlation on data obtained for lower IR of AHB (between $2 \%$ and $5 \%)$. In the present research the G Test of Independence did not indicate a significant difference between the number of dead larvae and the number of larvae which died on the $3^{\text {rd }}$ and $4^{\text {th }}$ days of life (inbreeding effect). So it can be concluded that the deaths occurred during the period cited by Laidlaw et al. (1956) did not contribute significantly to the total number of larval deaths.

\section{CONCLUSION}

The results obtained in this research revealed that in AHB colonies parasitized by Varroa destructor mortality rates of larvae under conditions of high infestation ranged from $15.71 \%$ to $16.15 \%(\bar{X}=15.93 \%)$. In the case of pupae, the frequencies of dead bees varied from $19.27 \%$ to $23.28 \%$ ( $\bar{X}$ $=21.27 \%$ ). Considering that in the control group the rate of dead bees was $3.74 \%$ in the larval stage and $3.85 \%$ in the pupal stage, it can be deduced that in the infested colonies the average rates of mortality caused by the harmful effects of the mite were, respectively, 4.26 times and 5.52 times greater in those two developmental stages. This implies a significant loss of developing bees in the colony and consequently a lower number of adults produced, which could be reflected directly on hive productivity. It proves that high IR could be significantly detrimental for beekeeping.

Thus it can be concluded that even in tropical regions, like Brazil, it is necessary to devote special attention to the levels of mite infestation (IR), particularly when the IR tends to be higher such as in winter, or in the case of susceptibility to the mite or weakening of the colony (caused by any reason).

\section{ACKNOWLEDGMENTS}

The authors are grateful to CAPES (Coordenação de Aperfeiçoamento de Pessoal de Nivel Superior) for the financial support of this research. 


\section{REFERENCES}

Anderson, D.L. 1994. Non-reproduction of Varroa jacobsoni in Apis mellifera colonies in Papua NewGuinea and Indonesia. Apidologie 25: 412-421.

Anderson, D. \& J. Trueman 2000. Varroa jacobsoni is more than one species. Experimental and Applied Acarology 24:165-189.

Anderson, D.L. \& Sukarsih 1996. Changed Varroa jacobsoni reproduction in Apis mellifera colonies in Java. Apidologie 27: 461-466.

Ayres, M., M. Ayres JR, D. Lima Ayres \& A. A. Santos Dos Santos 2007. BioEstat 5.0. Belém- PA, Brasil: Sociedade Civil Mamirauá, 2007, 364 p.

Ball, B.V. 1988. The impact of secondary infections in honey-bee colonies infested with the parasitic mite Varroa jacobsoni, pp. 457- 461. In: Needham G.R., R.E. Page, M. Delfinado-Baker \& C.E. Bowman (Eds.), Africanized Honeybees and Bee Mites.1988. Ellis Horwood Ltd., Chichester, UK.

Beestma, J., W.J. Boot \& J. Calis 1999. Invasion of Varroa jacobsoni Oud. from bees into brood cells. Apidologie 30: 125-140.

Beestma, J., R. de Vries, B.E. Yeganeh, M.E. Tabrizi \& V. Bandpay 1989. Effects of Varroa jacobsoni on colony development, worker bee weight and longevity and brood mortality, pp 163-170. In: Cavalloro R. (Ed.), Proc. EC Experts' Group Meeting, Udine, Italy.

Boecking, O. \& E. Genersch 2008. Varroosis - the ongoing crisis in bee keeping. Journal fur Verbrauch. Lebensm 3: 221-228.

Bogdanov, S. Contaminants of bee products. Apidologie 2006; 37:1-18.

Bowen-Walker, P.L., A. Gunn 2001. The effect of the ectoparasitic mite, Varroa destructor on adult worker honeybee (Apismellifera) emergence weights, water, protein, carbohydrate, and lipid levels. Entomologia Experimentalis et Applicata 101: 207- 217.

Bowen-Walker, P.L., S.J. Martin, A. Gunn 1999. The transmission of deformed wing virus between honeybees (Apis mellifera L.) by the ectoparasitic mite Varroa jacobsoni Oud. Journal of Invertebrate Pathology. 73:101- 106.

De Jong, D. 1984. Current knowledge and open question concerning reproduction in honey bee mite Varroa jacobsoni. Advances in Invertebrate Reproduction 3: 347352.

De Jong, D. 1997. Mites: Varroa and other parasites of brood, pp. 279-328. In: R. A. Morse \& K. Flottum (Eds.), Honey bee pests, predators and diseases.1997. The A. I. Root Company, Medina, Ohio.

De Jong, D., R.A. Morse \& G.E. Eickwort 1982. Mite pests of honey bees. Annual Review of Entomology 27:229-252.

De Jong, D., L. S. Gonçalves \& R. A. Morse 1984. Dependence of climate on the virulence of Varroa jacobsoni. Bee World 65: 117-121.

Delfinado-Baker, M., W. Rath, O. Boecking 1992. Phoretic bee mites and grooming behavior. International Journal of Acarology 18: 315-322.

Donzé, G. \& P. Guerin 1994. Behavioral attributes and parental care of Varroa mites parasiting honeybee brood. Behavioral Ecology and Sociobiology 34: 305-319. 
Elzen, P. J., F. A. Eischen, J. B. Baxter, J. Pettis, G.W. Elzen \& W.T. Wilson 1998. Fluvalinate resistance in Varroa jacobsoni from several geographic locations. American Bee Journal 138: 674-676.

Elzen, P.J., J.R. Baxter, M. Spivak \& W.T. Wilson 2000. Control of Varroa jacobsoni Oud. resistant to fluvalinate and amitraz using coumaphos. Apidologie 31: 437-441.

Erickson, E., A. Cohen \& B. Cameron 1994. Mite excreta: a new diagnostic for varroasis. Bee Science 3: 76-78.

Garedew, A., E. Schmolz \& I.Lamprecht 2004. The energy and nutritional demand of the parasitic life of the mite Varroa destructor. Apidologie 35: 419-430.

Garófalo, C. A. 1977. Brood viability in normal colonies of Apis mellifera. Journal of Apicultural Research 16: 3-13.

Genersch, E. 2005. Development of a rapid and sensitive RT-PCR method for the detection of deformed wing virus, a pathogen of the honeybee (Apis mellifera). Veterinary Journal 169: 121-123.

Gonçalves, L.S. 1986. The Varroa research program in the honey bee laboratory of the University of São Paulo in Ribeirão Preto. Apidologie 17: 371-374.

Gusman-Novoa, E., R. Valdame, M.E. Arechaveleta \& A. Sanches 1999. Susceptibility of European and Africanized bees (Apis mellifera L.) to Varroa jacobsoni Oud. Apidologie 30: 173-182.

Hillesheim, E., W. Ritter \& D. Bassand 1996. First data on resistance mechanisms of Varroa jacobsoni (Oud.) against tau-fluvalinate. Experimental and Applied Acarology 20, 283-296.

Ifantidis, M. D. \& P. Rosenkranz 1988. Reproduktion der Bienenmilbe Varroa jacobsoni (Acarina: Varroidae). Entomologia Generalis 14:111-122.

Jacobs, F., E. Bruneau \& J. Trouiller 1997. Resultaten van de campagne voor de opsporing van resistentie van Varroa jacobsoni t.o.v. pyrethrinoiden in België. Maandblad Vlaamse Imker Bond 83: 369-372.

Kralj, J. \& S. Fuchs 2006. Parasitic Varroa destructor mites influence flight duration and homing ability of infested Apis mellifera foragers. Apidologie 37: 577-587.

Laidlaw, H.H., F.P. Gomes \& W.E. Kerr 1956. Estimation of the number of lethal alleles in a panmitic population of Apis mellifera. Genetics 41: 179-188.

Le Conte, Y., M. Ellis \& W. Ritter 2010. Varroa mites and honey bee health: can Varroa explain part of the colony losses? Apidologie 41: 353-363.

Martel, A.C., S.Zeggane, C. Aurieres, P. Drajnudel, J.P. Faucon \& M. Aubert 2007. Acaricide residues in honey and wax after treatment of honey bee colonies with Apivar or Asuntol 50. Apidologie 38: 534-544.

Martin, S.J. 1998. A population model for the ectoparasitic mite Varroa jacobsoni in honey bee (Apis mellifera) colonies. Ecological Modeling 109:267-81.

Martin, S.J. 2001. The role of Varroa and viral pathogens in the collapse of honeybee colonies: a modelling approach. Journal of Applied Ecology 38:1082-1093. 
Mattos, I. M. \& J. Chaud-Netto 2011. Effects of Natural Infestations of the Mite Varroa destructor on the Development of Africanized Honeybee Workers (Apis mellifera). Sociobiology 58: 85-93.

Milani, N. 1995. The resistance of Varroa jacobsoni Oud. to pyrethroids: A laboratory assay. Apidologie 26: 415-429.

Milani, N. 1999. The resistance of Varroa jacobsoni Oudemans to acaricides. Apidologie 30: 229-234.

Montiel, E. J. C. \& G. A. Piola 1976. A new enemy of bees, pp. 36- 38. In: V. Harnaj (Ed.), Varroasis: a honey bee disease. 1977. Apimondia Publishing House, Bucharest.

Moretto, G., L. S. Gonçalves \& D. De Jong 1993. Heritability of Africanized and European honeybee defensive behavior against the mite Varroa jacobsoni. Revista Brasileira de Genética 16: 71-77.

Rocha, H.C. \& C. Almeida-Lara 1994. Flutuação populacional do ácaro Varroa jacobsoni O. em colméias de abelhas africanizadas, pp. 97-100. In: Congresso Iberolatinoamericano de Apicultura, 5. 1994. Córdoba. Anais. Córdoba: Sociedade Rural Rio Cuatro.

Romero-Vera, C. \& G. Otero-Colina 2002. Effect of single and successive infestation of Varroa destructor and Acarapiswoodi on the longevity of worker honeybees Apismellifera. American Bee Journal 142: 54-57.

Schatton-Gadelmayer, K. \& W. Engels 1988. Hemolymph proteins and body weight in newly emerged worker honey bees according to different rates of parasitation by brood mites ( Hymenoptera, Apidae: Apis mellifera, Acarina, Varroaidae: Varroa jacobsoni). Entomologia Generalis 14: 93-101.

Schneider, P. \& W. Drescher 1987. The influence of Varroa jacobsoni Oud. on weight, development of weight and hypopharyngeal glands, and longevity of Apis mellifera L. Apidologie 18:101-110.

Stort, A. C., L. S. Gonçalves, O. Malaspina \& F. A. Moura Duarte 1981. Study on sineacar effectiveness in controlling Varroa jacobsoni. Apidologie 12: 289-297.

Tentcheva, D., L. Gauthier, L. Bagny, J. Fievet, B. Dainat, F. Cousserans, M. E. Colin \& M. Bergoin 2006. Comparative analysis of deformed wing virus (DWV) RNA in Apis mellifera and Varroa destructor. Apidologie 37:41-50.

van Engelsdorp, D., J. D. Evans, C. Saegerman, C. Mullin, E. Haubruge, B. K. Nguyen, M. Frazier, J. Frazier, D. Cox-Foster, Y. Chen, R. Underwood, D. R. Tarpy \& J. S. Pettis 2009. Colony collapse disorder: a descriptive study. PLoS One 4(8): e6481. DOI:10.1371/ journal.pone.0006481.

Wallner, K. 1999. Varroacides and their residues in bee products. Apidologie 30:235-248.

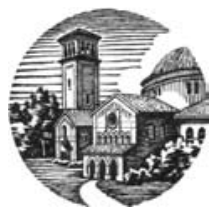

